DOI: https://doi.org/10.47405/mjssh.v6i3.702

\begin{tabular}{|c|c|}
\hline & Malaysian Journal of Social Sciences and Humanities (MJSSH) \\
\hline 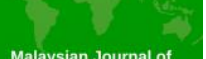 & Volume 6, Issue 3, March 2021 \\
\hline Humanities & e-ISSN : 2504-8562 \\
\hline & $\begin{array}{l}\text { Journal home page: } \\
\text { www.msocialsciences.com }\end{array}$ \\
\hline
\end{tabular}

\title{
Kesan Norma Baharu Terhadap Pengguna dari Aspek Aktiviti Sosial
}

\author{
Nur Amirah Adibah Norashikin', Nur Izzati Jaafar Sidek , Nur Ainiza Johari1, Mohamad Izzuan \\ Mohd Ishar ${ }^{1}$ \\ ${ }^{1}$ Sekolah Pendidikan, Fakulti Sains Sosial dan Kemanusiaan, Universiti Teknologi Malaysia (UTM)
}

Correspondence: Nur Izzati Jaafar Sidek (zatijaafar1234@gmail.com)

\begin{abstract}
Abstrak
Kajian berkaitan COVID-19 merupakan kajian yang baharu dan mula dikaji oleh para penyelidik pelbagai bidang di seluruh dunia bermula pada tahun 2020. Sehubungan itu, bidang sosiologi yang merangkumi aspek kemasyarakatan menjadi masalah kajian dalam penulisan ini. Kaedah kuantitatif digunakan untuk membincangkan dan menganalisis isu penularan wabak pandemik COVID-19 dalam lingkungan sosiologi masyarakat Malaysia yang mementingkan aktiviti sosial manusia. Penularan wabak pandemik COVID-19 ini mengakibatkan masyarakat terbatas untuk melakukan aktiviti sosial dan menjadi norma baharu dalam menjalani kehidupan seharian. Sehubungan itu, kajian ini adalah untuk menganalisis kesan COVID-19 dan membincangkan kes COVID-19 dari sudut aktiviti sosial dalam sosiologi masyarakat Malaysia yang serba baharu ini. Hasil dapatan ini jelas menunjukkan penurunan kadar kes COVID-19 di Malaysia dipengaruhi oleh tingkah laku sosial masyarakat Malaysia terhadap pematuhan sepanjang PKP ini dilaksanakan oleh kerajaan Malaysia. Sehubungan itu, kajian ini bertujuan untuk mengkaji kesan norma baharu masyarakat dari segi aktiviti sosial. Kajian ini dijalankan melalui pengedaran borang soal selidik secara atas talian kepada masyarakat setempat. Hasil dapatan kajian yang ditunjukkan membuktikan kesan yang dihadapi oleh masyarakat dalam menghadapi norma baru untuk melakukan aktiviti sosial seperti biasa.
\end{abstract}

Kata kunci: COVID-19, aktiviti sosial, masyarakat

\section{The Effect of New Norms on Consumer from the Social Aspect Activities}

\begin{abstract}
The study related to COVID-19 is a new study and began to be studied by researchers in various fields around the world starting in 2020. Accordingly, the field of sociology which includes aspects of society is a research problem in this writing. Quantitative methods are used to discuss and analyze the issue of the spread of the COVID-19 pandemic in the sociological environment of Malaysian society which emphasizes human social activity. The spread of the COVID-19 pandemic has resulted in the community being limited to social activities and becoming a new norm in their daily lives. Accordingly, this study is to analyze the effects of COVID-19 and discuss the case of COVID-19 in terms of social activities in the sociology of this all-new Malaysian society. These findings clearly show that the decrease in the rate of COVID-19 cases in Malaysia is influenced by the social behavior of the Malaysian community towards compliance during the MCO implemented by the Malaysian government. Accordingly, this study aims to examine the impact of new community norms in terms of social activities. This study was conducted through the distribution of questionnaires online to the
\end{abstract}


local community. The results of the study shown prove the impact faced by society in facing new norms to do social activities as usual..

Keywords: COVID-19, social activities, community

\section{Pengenalan}

Menurut Kementerian Kesihatan Malaysia,penyakit Coronavirus 2019 (COVID-19) telah mula dikesan di negara China dengan kes pertama disahkan pada 7 Januari 2020 di Wuhan, Hubei, China. Dalam tempoh tiga (3) minggu seterusnya, kes-kes disahkan di Thailand, Nepal, Amerika Syarikat, Korea Selatan, Singapura, Perancis, Vietnam dan Malaysia.COVID-19 adalah jangkitan pada saluran pernafasan dengan gejala demam, sakit tekak atau kesukaran bernafas dengan sejarah perjalanan ke negara China atau kontak rapat dengan kes. Kes pertama di Malaysia disahkan pada 25 Januari 2020 (CPRC, KKM: 17 Februari 2020). Fauzi (2020) juga menjelaskan bahawa pandemik bermula daripada penularan wabak pada peringkat epidemik yang merebak secara meluas sehingga tidak dapat dikawal dan mampu membunuh ramai orang dalam masa yang singkat. Isu pandemik COVID-19 ini juga telah memberi impak dalam kehidupan masyarakat Malaysia yang merangkumi aktiviti sosial masyarakat.

Pandemik COVID-19 ini memberikan kesan yang mendalam kepada masyarakat dari segi kesihatan, aktiviti sosial dan lain-lain sehingga mengakibatkan beberapa negara termasuk Malaysia mengambil langkah menjalankan Perintah Kawalan Pergerakan (PKP). Rakyat dinasihatkan untuk terus kekal di rumah, bekerja dari rumah (Work From Home), pergerakan di luar rumah dihadkan, memakai pelitup hidung dan mulut, kerap cuci tangan, menjaga penjarakan sosial dan sebagainya sebagai langkahlangkah pencegahan pandemik ini. Salah satu cabaran yang diberi perhatian ialah isu dimana masyarakat terbatas dalam melakukan aktiviti harian seperti biasa. Dalam hal ini, masyarakat dihadkan untuk melakukan aktiviti sosial atau riadah yang melibatkan tempat awam. Tujuan penulisan kajian ini ialah sebagai perbincangan mengenai kesan aktiviti sosial sepanjang pandemik COVID-19. Namun, skop perbincangan lebih tertumpu kepada kesan aktiviti sosial pandemik kepada masyarakat.

\section{Objektif}

Tujuan kajian terhadap kesan norma baharu terhadap pengguna dari aspek aktiviti sosial ialah:

i. Mengenal pasti kesan aktiviti sosial yang hadapi oleh masyarakat sebelum pandemik COVID19.

ii. Mengenal pasti kesan aktiviti sosial yang hadapi oleh masyarakat selepas pandemik COVID19.

iii. Mengkaji faktor yang mempengaruhi perubahan aktiviti sosial pengguna di Malaysia.

\section{Kajian Literatur}

Sejak COVID-19 melanda dunia, kesan buruk ke atas ekonomi tercetus di kebanyakan negara. Krisis COVID-19 yang disusuli dengan penutupan sempadan dan negara telah memberi kejutan ekonomi untuk melakukan aktiviti sosial seperti norma biasa (Johnsen, 2020). Akibatnya, pandemik COVID-19 mendorong tercetusnya implikasi buruk terhadap semua aspek kehidupan komuniti, baik secara langsung atau tidak langsung iaitu bermula apabila mereka mula jatuh sakit, kemudian dikenakan sekatan sosial oleh pemerintah sehingga tergendalanya aktiviti ekonomi sekali gus mempengaruhi pendapatan isi rumah dan perniagaan di luar bandar (Philipson, 2020). Menurut Dube dan Kathende (2020), sewaktu arahan penutupan dan penyekatan sosial berlangsung, tidak semua golongan masyarakat mampu berdiam diri di rumah tanpa membuat sebarang aktiviti sosial untuk mengisi kelapangan sepanjang musim COVID-19. 
Dalam hal ini, mengakibatkan kewujudan pelbagai sekatan telah mencetuskan suasana yang mendorong kepada tekanan, keresahan dan kemurungan di kalangan masyarakat dalam negara ini secara lebih meluas kerana pergerakan mereka kian terbatas dan mempunyai limit untuk melakukan aktiviti riadah seperti norma biasa. Sementara itu di Malaysia, Perutusan Khas Perdana Menteri pada 16 Mac 2020 turut mengumumkan Perintah Kawalan Pergerakan (PKP) Fasa 1 yang bermula sejak 18 Mac 2020 hingga 31 Mac 2020 sebagai langkah pencegahan dan penularan pandemik COVID-19 di negara ini. Sehubungan itu, kaedah teknologi IR4.0 telah menjadi penting dalam situasi wujudnya pelbagai kebiasaan baharu seperti amalan penjarakan sosial, saringan kesihatan bagi yang berisiko dan halangan menghadiri aktiviti berkelompok. Kebimbangan ini ditambahkan lagi dengan ketidakpastian bila PKP ini akan berakhir. Pastinya situasi ini memberi impak tidak dijangka dalam perlaksanaan U4S disebabkan aktiviti pemindahan ilmu bagi menyantuni masyarakat dilakukan secara turun padang dan bersemuka.

Berikutan dari wabak ini, rakyat Malaysia secara amnya telah menjalani kehidupan norma baharu, di mana rata-rata daripada kita sendiri tidak sedar kehidupan yang kita jalani pada masa kini lebih efektif dan berkualiti daripada sebelum pandemik berlaku. Rakyat Malaysia disarankan untuk sentiasa kekal aktif walaupun diarahkan untuk berada di rumah. Antara langkah utama semasa PKP ini adalah penutupan sempadan antara negeri dan juga sempadan negara. Langkah drastik ini sememangnya perlu dilakukan bagi mengawal penularan wabak COVID-19, namun industri pelancongan negara adalah pihak yang paling terjejas dalam situasi ini. Industri pelancongan negara terutamanya yang berkaitan dengan penginapan, pengangkutan, membeli -belah, makanan dan minuman, dan penganjuran acara perniagaan (Meetings, Incentives, Conventions and Exhibitions - MICE) telah terjejas teruk. Tingkah laku pengguna telah berubah susulan impak yang dicetuskan pandemik COVID-19, justeru normal baharu mungkin menjadi kelaziman yang berkekalan. Perubahan trend dalam pembelian oleh pengguna juga telah berubah akibat daripada pandemik COVID-19 ini. Pusat beli-belah hari ini, sejak $4 \mathrm{Mei}$, dapati rakyat beransur-ansur keluar namun ini memerlukan masa.

Antara respons semasa tempoh PKP adalah menerima menggunakan e-dagang, yang didapati mencatatkan trafik dan pembelian lebih tinggi sejak PKP bermula. Pembeli baharu kini merangkumi 40 peratus daripada semua jualan dalam talian. Tren pembelian secara dalam talian menjadi semakin popular atau trend terkini dalam memperoleh sesuatu barang selepas pandemik ini. Mekanisme dagangan secara dalam talian mempunyai pelbagai platform. Antara platform dalam talian popular di negara ini ialah Lazada dan Shopee. Malah, ada juga peniaga menggunakan media sosial seperti Facebook, Instagram dan blog. Langkah-langkah penjarakan sosial dikenakan kerana coronavirus telah menjangkiti pengguna dalam seluruh aspek kehidupan, termasuk bagaimana mereka membeli barangan runcit. Meskipun membeli belah barangan runcit dalam kedai merupakan saluran pilihan utama, lebih sepertiga daripada pengguna kini membeli makanan secara dalam talian, dan yang membeli belah dalam talian ini merancang untuk meneruskannya selepas langkah-langkah penjarakan sosial ditamatkan. Bagi item bukan makanan, sebelum berlakunya pandemik aktiviti membeli belah dalam kedai masih dominan berbanding dengan membeli belah dalam talian.

Pengguna berkata mereka membeli belah di kedai fizikal setiap hari atau mingguan berbanding membeli belah melalui telefon mudah alih, atau komputer. Sejak dari pandemik, membeli belah dalam talian untuk barangan bukan makanan telah menyaksikan peningkatan yang tinggi menggunakan telefon mudah alih, komputer dan komputer. Namun bagi pengguna yang mempunyai "member card" bagi sesebuah organisasi seperti gym, restoran terpilih dan banyak lagi juga akan berubah. Dimana pada masa kini pengguna tidak dapat menggunakan keistimewaan tersebut kerana pandemik ini telah menyekat kebebasan pengguna untuk membuat aktiviti seperti pergi ke gym dan juga makan di restoran. Pengguna tidak lagi boleh bebas untuk datang ke gym untuk membuat aktiviti yang biasa mereka lakukan kerana kawalan bilangan pengguna yang boleh menggunakan gym pada satu-satu masa. Oleh itu, kesan norma baharu dari segi aktiviti sosial masyarakat ini sedikit sebanyak memberikan impak besar kepada pengguna untuk melakukan riadah, membeli belah dan bersantai bersama ahli keluarga. Namun sedemikian, norma baru ini juga memberikan satu kelainan kepada pengguna untuk berbelanja melalui dunia online yang kian maju ini. Bahkan kesan psikologi COVID19 atau Perintah Kawalan Pergerakan menjadikan masyarakat lebih berhati-hati semasa keluar rumah dan mereka keluar apabila perlu sahaja. 


\section{Metod Kajian}

Menurut Hornby (1985), metodologi merupakan satu set kaedah yang digunakan untuk menjalankan kajian ke atas subjek kajian yang tertentu. Kajian ini merupakan satu kajian deskriptif. Pengkaji menggunakan reka bentuk kajian kuantitatif dan borang soal selidik sebagai instrumen. Sasaran responden kajian ini orang awam yang berumur 15 tahun ke atas. Semua maklumat dianalisis untuk menjawab persoalan kajian ini. Pengkaji juga mengedarkan borang soal selidik secara atas talian kepada responden. Jumlah populasi dalam kajian ini ialah seramai 30 orang. Borang soal selidik ini mengandungi empat bahagian iaitu bahagian A merangkumi demografi, bahagian B merangkumi aktiviti sosial sebelum pandemik COVID-19, bahagian C merangkumi aktiviti sosial selepas pandemik COVID-19 dan bahagian D merangkumi faktor mempengaruhi perubahan aktiviti sosial konsumer di Malaysia. Jumlah soalan ialah 22 soalan yang merangkumi empat bahagian tersebut. Pengkaji juga menggunakan skor skala Likert dari 1 hingga 5 iaitu 1 (sangat tidak setuju), 2 (tidak setuju), 3 (tidak pasti), 4 (setuju), 5 (sangat setuju). Pengkaji juga menggunakan data sekunder iaitu data yang boleh dirujuk seperti data yang telah dikumpulkan oleh pengkaji lain. Data-data yang lepas atau terdahulu dikumpulkan telah digunakan oleh pengkaji dalam kajian ini. tujuan kajian. Pengkaji telah menggunakan buku ilmiah, laporan formal, majalah dan surat khabar untuk pengumpulan data.

\section{Analisis Kajian}

\section{Analisis Demografi kajian}

Maklumat responden merupakan elemen penting dalam kajian ini kerana maklumat tersebut menceritakan maklumat dan latar belakang responden. Latar belakang responden berbeza dapat memberi pandangan yang unik terhadap isu perbincangan kajian ini. Maklumat responden yang dikajikan dalam kajian ini merangkumi jantina, umur, pekerjaan dan pendapatan.

Carta 1: Jantina Responden

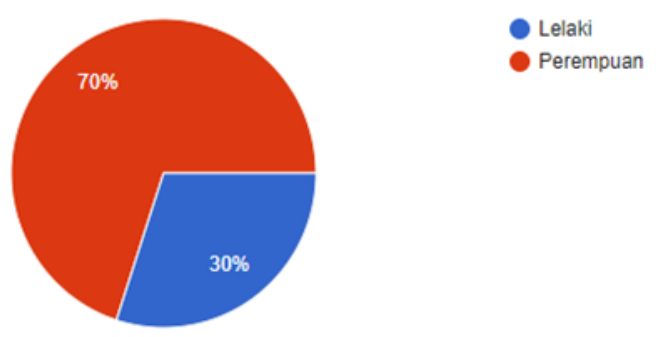

Carta 1 menunjukkan jumlah peratusan jantina responden dalam soal selidik kajian ini. Responden dalam kajian ini terdiri daripada 30\% pelajar lelaki dan 70\% pelajar perempuan. Jumlah keseluruhan responden adalah seramai 30 orang awam di Malaysia. Carta ini menunjukkan terdapat peratusan responden perempuan yang lebih banyak berbanding responden lelaki dalam kajian yang dijalankan ini.

Carta 2 : Umur Responden

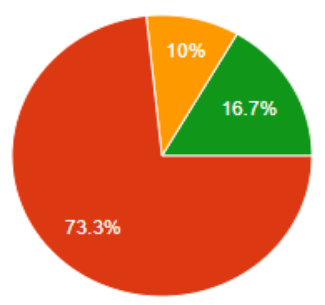

15 hingga 19 tahun

20 hingga 24 tahun

25 hingga 29 tahun

30 tahun ke atas 
Carta 2 menunjukkan peratusan umur responden yang menjawab soal selidik ini. Sebanyak $73.3 \%$ yang berumur dari 20 tahun sehingga 24 tahun. $16.7 \%$ pula berumur 30 tahun ke atas. Seterusnya, carta 2 menunjukkan peratusan umur dari 25 tahun hingga 29 tahun hanya 10\%. Peratusan umur 15 tahun sehingga 19 tahun menunjukkan nilai sifar. Ia menunjukkan majoriti responden terdiri daripada umur 20 tahun sehingga 24 tahun yang menjawab soal selidik ini.

Carta 3 : Pekerjaan Responden

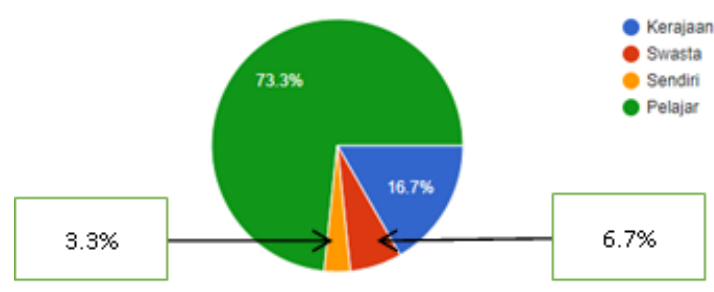

Carta 3 menunjukkan jumlah peratusan pekerjaan 30 responden. Responden yang masih belajar menunjukkan peratusan paling tertinggi di antara sektor pekerjaan yang lain iaitu $73.3 \%$. Sektor kerajaan pula menunjukkan jumlah peratusan $16.7 \%$, diikuti dengan sektor swasta iaitu $6.7 \%$. dan bekerja sendiri pula menunjukkan 3.3\%. Ia menunjukkan bahawa kebanyakan responden dalam kajian ini terdiri daripada pelajar.

Carta 4 : Pendapatan Responden

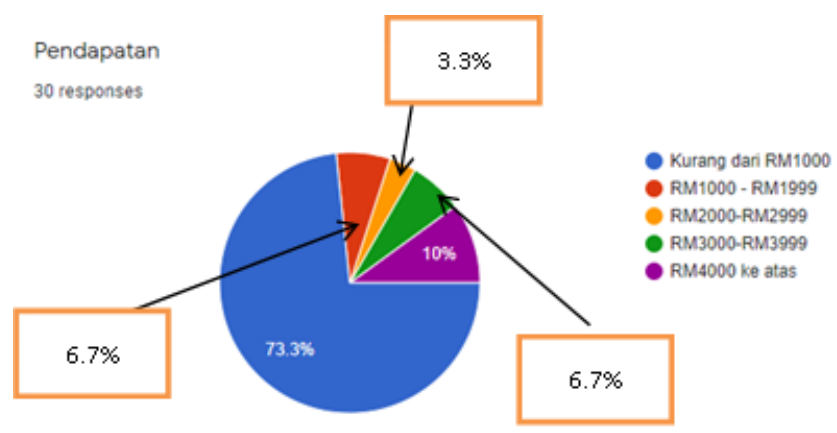

Carta 4 ini menunjukkan jumlah peratusan pendapatan 30 responden dalam kajian ini. Jumlah peratusan yang paling rendah sebanyak 3.3\% iaitu dari jumlah pendapatan RM 2000-RM 2999. Selain itu, jumlah peratusan untuk pendapatan RM 1000-RM 1999 dan RM 3000-RM 3999 menunjukkan peratusan yang sama iaitu 6.7\%. Jumlah peratusan untuk pendapatan RM 4000 ke atas ialah 10\%. Akhirnya jumlah yang tertinggi peratusannya sebanyak 73.3\% ialah pendapatan kurang dari RM 1000 . Ia menunjukkan pendapatan responden majoriti kurang dari RM 1000.

\section{Analisa Maklum Balas Kesan Aktiviti Sosial yang Hadapi oleh Masyarakat Sebelum Pandemik COVID-19}

Bagi mengkaji aktiviti sosial kosumer di Malaysia sebelum berlakunya wabak pandemik COVID-19, 7 item soalan telah dibina secara dalam talian. Jadual 1 menunjukkan peratusan dapatan kajian bagi setiap item untuk mengkaji aktiviti sosial konsumer di Malaysia sebelum wabak pandemik COVID19. Item soalan ini telah dibina dengan menggunakan skala likert 1 hingga 5 iaitu skala 1 ialah sangat tidak setuju (STS), skala 2 tidak setuju (TS), skala 3 tidak pasti (TP), skala 4 setuju (S) dan skala 5 adalah sangat setuju (SS).

Hasil kajian menunjukkan item soalan 1 menunjukkan majoriti responden iaitu seramai 16 orang (53.3\%) sangat setuju dan seramai 8 responden (26.7\%) setuju bahawa mereka berbelanja di pusat membeli-belah bersama ahli keluarga dan rakan sebelum pandemik COVID-19 ini adalah kerana sebelum pandemik semuanya berasa selamat dari sebarang jangkitan virus. Namun ada juga yang tidak 
DOI: https://doi.org/10.47405/mjssh.v6i3.702

setuju (10\%) dan sangat tidak setuju (6.7\%) pergi berbelanja di pusat membeli-belah bersama ahli keluarga dan rakan. Ini adalah kerana mereka lebih gemar membeli-belah secara dalam talian sahaja.

Jadual 1: Kesan Aktiviti Sosial Sebelum COVID-19

\begin{tabular}{|c|c|c|c|c|c|}
\hline Pernyataan & $\begin{array}{c}1 \\
(\mathrm{STS})\end{array}$ & $\begin{array}{c}2 \\
(\mathrm{TS})\end{array}$ & $\begin{array}{c}3 \\
(\mathbf{T P})\end{array}$ & $\begin{array}{c}4 \\
(S)\end{array}$ & $\begin{array}{c}5 \\
(\mathrm{SS})\end{array}$ \\
\hline $\begin{array}{l}\text { Berbelanja di pusat } \\
\text { membeli-belah } \\
\text { bersama ahli keluarga dan } \\
\text { rakan }\end{array}$ & $\begin{array}{c}2 \\
(6.7 \%)\end{array}$ & $\begin{array}{c}3 \\
(10 \%)\end{array}$ & $\begin{array}{c}1 \\
(3.3 \%)\end{array}$ & $\begin{array}{c}8 \\
(26.7 \%)\end{array}$ & $\begin{array}{c}16 \\
(53.3 \%)\end{array}$ \\
\hline $\begin{array}{l}\text { Mengunjungi mana-mana } \\
\text { premis atau pusat membeli- } \\
\text { belah tanpa perlu "scan" } \\
\text { MySejahtera dan } \\
\text { menggunakan "hand } \\
\text { sanitizer" }\end{array}$ & $\begin{array}{c}5 \\
(16.7 \%)\end{array}$ & $\begin{array}{c}3 \\
(10 \%)\end{array}$ & $\begin{array}{c}10 \\
(33.3 \%)\end{array}$ & $\begin{array}{c}8 \\
(26.7 \%)\end{array}$ & $\begin{array}{c}4 \\
(13.3 \%)\end{array}$ \\
\hline $\begin{array}{l}\text { Mengunjungi pusat } \\
\text { kecergasan seperti gym } \\
\text { pada setiap hari atau setiap } \\
\text { minggu }\end{array}$ & $\begin{array}{c}5 \\
(16.7 \%)\end{array}$ & $\begin{array}{c}3 \\
(10 \%)\end{array}$ & $\begin{array}{c}10 \\
(33.3 \%)\end{array}$ & $\begin{array}{c}8 \\
(26.7 \%)\end{array}$ & $\begin{array}{c}4 \\
(13.3 \%)\end{array}$ \\
\hline $\begin{array}{l}\text { Bercuti bersama ahli } \\
\text { keluarga dan rakan sama } \\
\text { ada dalam negara atau luar } \\
\text { negara }\end{array}$ & $\begin{array}{c}4 \\
(13.3 \%)\end{array}$ & $\begin{array}{c}2 \\
(6.7 \%)\end{array}$ & $\begin{array}{c}6 \\
(20 \%)\end{array}$ & $\begin{array}{c}7 \\
(23.3 \%)\end{array}$ & $\begin{array}{c}11 \\
(36.7 \%)\end{array}$ \\
\hline $\begin{array}{l}\text { Kerap "dine in" } \\
\text { apabila makan di kedai } \\
\text { makan }\end{array}$ & $\begin{array}{c}1 \\
(3.3 \%)\end{array}$ & $\begin{array}{c}1 \\
(3.3 \%)\end{array}$ & $\begin{array}{c}4 \\
(13.3 \%)\end{array}$ & $\begin{array}{c}11 \\
(36.7 \%)\end{array}$ & $\begin{array}{c}13 \\
(43.3 \%)\end{array}$ \\
\hline $\begin{array}{l}\text { Melakukan aktiviti riadah } \\
\text { secara berkumpulan atau } \\
\text { beramai-ramai bersama } \\
\text { ahli keluarga dan rakan }\end{array}$ & $\begin{array}{c}1 \\
(3.3 \%)\end{array}$ & $\begin{array}{c}3 \\
(10 \%)\end{array}$ & $\begin{array}{c}4 \\
(13.3 \%)\end{array}$ & $\begin{array}{c}8 \\
(26.7 \%)\end{array}$ & $\begin{array}{c}14 \\
(46.7 \%)\end{array}$ \\
\hline $\begin{array}{l}\text { Menggunakan } \\
\text { perkhidmatan atas talian }\end{array}$ & $\begin{array}{c}4 \\
(13.3 \%) \\
\end{array}$ & $\begin{array}{c}6 \\
(20 \%) \\
\end{array}$ & $\begin{array}{c}7 \\
(23.3 \%) \\
\end{array}$ & $\begin{array}{c}7 \\
(23.3 \%) \\
\end{array}$ & $\begin{array}{c}6 \\
(20 \%) \\
\end{array}$ \\
\hline
\end{tabular}

Bagi item soalan kedua pula majoriti responden menyatakan tidak pasti iaitu seramai 10 orang (33.3\%). Manakala bagi sangat tidak setuju dan tidak setuju masing-masing mencatatkan seramai 5 orang $(16.7 \%)$ dan 3 orang $(10 \%)$. Ini adalah kerana soalan soal selidik ini diedarkan setelah berlakunya pandemik dan responden telah terbiasa dengan norma baharu selepas pandemik dimana setiap kali mengunjungi mana-mana premis atau pusat membeli-belah perlu "scan" MySejahtera dan menggunakan "hand sanitizer". Jadi kebanyakan responden keliru dengan item soalan kedua ini dimana ianya item soalan kedua merujuk sebelum berlakunya pandemik. Namun seramai 8 responden (26.7\%) yang setuju dan seramai 4 responden (13.3\%) sangat setuju dimana mereka tidak perlu "scan" MySejahtera dan menggunakan "hand sanitizer" kerana iainya bukanlah satu SOP yang telah ditetapkan oleh kerajaan sebelum berlakunya pandemik.

Item soalan ketiga juga majoriti menjawab tidak pasti dimana seramai 10 responden (33.3\%). Selain itu, seramai 5 responden (16.7\%) dan 3 responden (10\%) masing-masing menjawab sangat tidak setuju dan tidak setuju. Ini adalah kerana responden ini tidak berapa gemar atau tidak berkesempatan mengunjungi pusat kecergasan seperti gym pada setiap hari atau setiap minggu walaupun sebelum berlakunya pandemik. Namun begitu, seranai 8 responden (26.7\%) setuju dan 4 responden (13.3\%) sangat setuju untuk mengunjungi pusat kecergasan seperti gym pada setiap hari atau setiap minggu ini adalah kerana mereka merupakan seorang yang mengamalkan gaya hidup yang sihat. 
Bagi item soalan keempat majoriti responden menjawab sangat setuju iaitu seramai 11 responden (36.7\%) dan seramai 7 responden (23.3\%) menjawab setuju bercuti bersama ahli keluarga dan rakanrakan sama ada dalam negara atau luar negara. Ini adalah kerana sebelum pandemik aktiviti melancong merupakan aktiviti sosial yang sangat popular dalam kalangan rakyat Malaysia. Namun ada juga responden yang menjawab tidak pasti iaitu seramai 6 responden (20\%), tidak setuju seramai 2 responden $(6.7 \%)$ dan sangat tidak setuju seramai 4 responden $(13.3 \%)$. Ini adalah kerana responden tersebut tidak berapa suka untuk melakukan aktiviti bercuti sama ada dalam negara atau luar negara.

Item soalan kelima menunjukkan majoriti responden menjawab sangat setuju iaitu seramai 13 responden (43.3\%) dan 11 responden (36.7\%) yang kerap "dine in" apabila makan di kedai makan. Ini adalah kerana "dine in" di kedai terus adalah mudah dan konsumer boleh menikmati pelbagai servis yang disediakan oleh pihak restoran. Namun ada juga responden yang menjawab tidak pasti iaitu seramai 4 responden (13.3\%). Ini adalah kerana mereka tidaklah kerap "dine in" tetapi kadang-kadang sahaja. Bagi sangat tidak setuju dan tidak setuju masing-masing mencatatkan seramai seorang responden (3.3\%) dimana mereka tidak suka "dine in" tetapi lebih gemar membungkus makanan.

Seterusnya bagi item soalan keenam pula seramai 14 responden (46.7\%) sangat setuju dan seramai 8 responden $(26.7 \%)$ setuju melakukan aktiviti riadah secara berkumpulan atau beramai-ramai bersama ahli keluarga dan rakan. Ini adalah kerana aktiviti riadah merupakan satu aktiviti yang sangat digemari oleh penduduk Malaysia untuk melepaskan tekanan dari tempat kerja. Namun, ada juga responden yang tidak setuju (10 orang) dan seramai seorang (3.3\%) sangat tidak setuju untuk beriadah secara berkumpulan atau bersama-sama ahli keluarga dan rakan. Ini adalah kerana mereka tidak berminat dalam melakukan sebarang aktiviti riadah. Akhir sekali seramai 4 responden (13.3\%) yang menjawab tidak pasti.

Bagi item soalan yang terakhir iaitu soalan ketujuh pula responden majoriti setuju dan tidak pasti di mana masing-masing mencatatkan seramai 7 responden (23.3\%) dan 6 responden (20\%) yang sangat setuju. Ini adalah kerana responden yang menjawab tidak pasti adalah kerana mereka merupakan pengguna yang neutral dimana mereka kerap dan juga jarang menggunakan perkhidmatan atas talian. Manakala bagi responden yang setuju dan sangat setuju pula mereka kurang menggunakan perkhidmatan atas talian seperti perkhidmatan Grab Food, FoodPanda dan banyak lagi. Untuk responden yang menjawab tidak setuju adalah seramai 6 responden (20\%) dan sangat tidak setuju adalah seramai 4 responden (13.3\%). Ini adalah kerana walaupun sebelum berlakunya pandemik, mereka kerap menggunakan perkhidmatan atas talian.

\section{Analisa Maklum Balas Kesan Aktiviti Sosial yang Hadapi oleh Masyarakat Selepas Pandemik COVID-19}

Bagi mengkaji aktiviti sosial kosumer di Malaysia selepas berlakunya wabak pandemik COVID-19, 7 item soalan telah dibina secara dalam talian. Jadual 2 menunjukkan peratusan dapatan kajian bagi setiap item untuk mengkaji aktiviti sosial konsumer di Malaysia selepas wabak pandemik COVID-19. Item soalan ini telah dibina dengan menggunakan skala likert 1 hingga 5 iaitu skala 1 ialah sangat tidak setuju (STS), skala 2 tidak setuju (TS), skala 3 tidak pasti (TP), skala 4 setuju (S) dan skala 5 adalah sangat setuju (SS).

Hasil kajian menunjukkan item soalan 1 iaitu tidak mengunjungi pusat membeli-belah langsung selepas berlakunya pandemik COVID-19 majoriti responden memilih tidak pasti dan tidak setuju dimana masing-masing mencatatkan seramai 8 responden (26.7\%). Ini adalah kerana selepas berlakunya pandemik COVID-19 ini, kerajaan telah melaksanakan perintah kawalan pergerakan sehingga dapat melandaikan jumlah kes positif. Seterusnya kerajaan telah memberikan kebenaran kepada rakyat untuk melakukan aktiviti sosial seperti pergi ke pusat membeli-belah dengan mengikut SOP yang ditetapkan. Oleh itu, majoriti responden tidak setuju jika dikatakan tidak pergi ke pusat membeli-belah langsung. Jumlah responden yang menjawab setuju dan sangat setuju pula adalah sama iaitu seramai 7 responden (23\%). Ini merupakan kelompok yang tidak mahu terdedah dengan orang ramai, jadi mereka memilih untuk tidak pergi ke pusat membeli-belah. 
Jadual 2: Kesan Aktiviti Sosial Selepas COVID-19

\begin{tabular}{|c|c|c|c|c|c|}
\hline Kenyataan & $\begin{array}{c}1 \\
(\mathrm{STS})\end{array}$ & $\begin{array}{c}2 \\
(\mathrm{TS})\end{array}$ & $\begin{array}{c}3 \\
(\mathbf{T P})\end{array}$ & $\begin{array}{r}4 \\
(S)\end{array}$ & $\begin{array}{c}5 \\
(\mathrm{SS})\end{array}$ \\
\hline $\begin{array}{l}\text { Tidak mengunjungi pusat } \\
\text { membeli-belah langsung }\end{array}$ & $\begin{array}{c}0 \\
(0 \%)\end{array}$ & $\begin{array}{c}8 \\
(26.7 \%)\end{array}$ & $\begin{array}{c}8 \\
(26.7 \%)\end{array}$ & $\begin{array}{c}7 \\
(23 \%)\end{array}$ & $\begin{array}{c}7 \\
(23 \%)\end{array}$ \\
\hline $\begin{array}{l}\text { Mengunjungi pusat membeli- } \\
\text { belah atau premis dengan } \\
\text { memakai pelitup muka, scan } \\
\text { MySejahtera dan menggunakan } \\
\text { hand sanitizer }\end{array}$ & $\begin{array}{c}0 \\
(0 \%)\end{array}$ & $\begin{array}{c}0 \\
(0 \%)\end{array}$ & $\begin{array}{c}0 \\
(0 \%)\end{array}$ & $\begin{array}{c}8 \\
(26.7 \%)\end{array}$ & $\begin{array}{c}22 \\
(73 \%)\end{array}$ \\
\hline $\begin{array}{l}\text { Tidak berkunjung kekawasan } \\
\text { yang sesak dengan } \\
\text { orang ramai }\end{array}$ & $\begin{array}{c}0 \\
(0 \%)\end{array}$ & $\begin{array}{c}0 \\
(0 \%)\end{array}$ & $\begin{array}{c}6 \\
(20 \%)\end{array}$ & $\begin{array}{c}6 \\
(20 \%)\end{array}$ & $\begin{array}{c}18 \\
(60 \%)\end{array}$ \\
\hline $\begin{array}{l}\text { Membungkus makanan di } \\
\text { kedai makan atau } \\
\text { menggunakan perkhidmatan } \\
\text { penghantaran } \\
\text { makanan }\end{array}$ & $\begin{array}{c}0 \\
(0 \%)\end{array}$ & $\begin{array}{c}3 \\
(10 \%)\end{array}$ & $\begin{array}{c}1 \\
(3.3 \%)\end{array}$ & $\begin{array}{c}4 \\
(13.3 \%)\end{array}$ & $\begin{array}{c}22 \\
(73 \%)\end{array}$ \\
\hline $\begin{array}{l}\text { Kurang mengunjungi pusat } \\
\text { kecergasan seperti gym, futsal } \\
\text { Atau pusat badminton }\end{array}$ & $\begin{array}{c}0 \\
(0 \%)\end{array}$ & $\begin{array}{c}0 \\
(0 \%)\end{array}$ & $\begin{array}{c}6 \\
(20 \%)\end{array}$ & $\begin{array}{c}8 \\
(26.7 \%)\end{array}$ & $\begin{array}{c}16 \\
(53.3 \%)\end{array}$ \\
\hline $\begin{array}{l}\text { Tidak pergi bercuti bersama } \\
\text { ahli keluarga atau rakan sama } \\
\text { ada di dalam negara atau luar }\end{array}$ & $\begin{array}{c}0 \\
(0 \%)\end{array}$ & $\begin{array}{c}1 \\
(3.3 \%)\end{array}$ & $\begin{array}{c}5 \\
(16.7 \%)\end{array}$ & $\begin{array}{c}10 \\
(16.7 \%)\end{array}$ & $\begin{array}{c}14 \\
(46.7 \%)\end{array}$ \\
\hline
\end{tabular}

Bagi item soalan kedua pula, majoriti responden menjawab sangat setuju dan setuju iaitu 22 responden (73\%) dan 8 responden (26.7\%). Manakala bagi skala sangat tidak setuju, tidak setuju dan tidak pasti masing-masing adalah 0 responden. Ini adalah kerana, pengguna selepas pandemik COVID-19 ratarata sudah terbiasa dengan norma baharu dan patuh pada SOP dimana mengunjungi pusat membelibelah dan premis, mereka "scan" MySejahtera dan menggunakan "hand sanitizer". Seterusnya, bagi item soalan ketiga, majoriti menjawab sangat setuju bagi soalan todak berkunjung ke kawasan yang sesak dengan orang ramai iaitu seramai 18 responden (60\%) dan 6 responden (20\%) memilih setuju dan tidak pasti. Ini adalah kerana, berada di kawasan yang sesak dengan orang ramai akan menyebabkan risiko jangkitan COVID-19 adalah tinggi, maka pengguna ingin mengurangkan dan mengelakkan dari risiko terkena jangkitan COVID-19 tersebut.

Item soalan keempat pula majoriti memilih sangat setuju iaitu seramai 22 responden (73\%) dan setuju adalah seramai 4 responden (13.3\%). Ini adalah kerana pengguna lebih suka untuk membungkus makanan selepas pandemik untuk mengurangkan interaksi dengan orang ramai atau berada di kawasan sesak. Ini adalah bagi mengurangkan risiko daripada terkena jangkitan COVID-19 yang masih belum menemui jalan penyelesaian ataupun vaksin yang berkesan. Seramai 3 responden (10\%) yang tidak setuju untuk membungkus makanan dari kedai makan. Ini adalah kerana sama ada mereka gemar untuk makan di kedai dengan mematuhi SOP yang dikeluarkan kerajaan ataupun mereka lebih gemar untuk makan di rumah.

Bagi item soalan kelima pula, ialah kurang mengunjungi pusat kecergasan seperti gym, futsal atau badminton. Majoriti memilih sangat setuju iaitu seramai 16 responden (53.3\%) dan 8 responden (26.7\%) memilih setuju. Ini adalah kerana mereka ingin mengurangkan daripada terdedah dengan risiko jangkitan dan kawasan orang ramai. Selain itu, pusat-pusat kecergasan telah menetapkan jumlah bilangan pengguna yang boleh masuk ke pusat kecergasan bagi mengurangkan bilangan dalam pada satu-satu masa. Oleh itu, lebih ramai pengguna tidak mengunjungi pusat kecergasan. Namun ada juga 
responden yang memilih tidak pasti iaitu seramai 6 responden (20\%). Ini adalah kerana mereka bersikap neutral dimana mereka kadang-kadang berkunjung ke pusat kecergasan tetapi tidak kerap.

Untuk item soalan keenam majoriti menjawab sangat setuju dimana seramai 14 responden $(46.7 \%)$ dan 10 responden (16.7\%) menjawab setuju. Ini adalah kerana ramai pengguna yang lebih suka duduk di rumah atau "trademark" pada zaman norma baharu iaitu "stay at home". Bagi pengguna yang sering melancong ke luar negara mereka terpaksa berhenti seketika aktiviti tersebut kerana kerajaan masih lagi tidak membuka "boarder". Namun ada juga responden yang menjawab tidak pasti iaitu seramai 5 responden (16.7\%). Ini adalah kerana mereka bersikap neutral dimana beliau tidak bersetuju untuk tidak bercuti bersama keluarga sama ada dalam negara atau luar negara tetapi yang penting mematuhi SOP yang ditetapkan.

Item soalan yang terakhir iaitu soalan ketujuh majoriti memilih sangat setuju iaitu seramai 14 responden $(48.3 \%)$ dan 8 responden $(27.6 \%)$ memilih setuju. Ini adalah kerana apabila berlakunya pandemik COVID-19 ini pengguna telah terbiasa dengan membeli barangan atau makanan hanya dengan menggunakan aplikasi dalam talian yang membolehkan mereka tidak berinteraksi secara langsung dengan orang ramai. Namun ada responden yang menjawab sangat tidak setuju iaitu 2 responden $(6.9 \%)$ dan seorang (3.4\%). Ini adalah kerana mereka lebih suka untuk berkunjung terus ke kedai atau premis membeli belah itu sendiri untuk melihat barang yang hendak dibeli tetapi dengan mematuhi SOP yang dikeluarkan oleh kerajaan. Seramai 4 responden (13.8\%) yang menjawab tidak pasti. Ini adalah kerana mereka tidak setuju atau bersetuju dengan kenyataan "kerap menggunakan perkhidmatan atas talian" kerana mereka mungkin menggunakan perkhidmatan atas talian tetapi tidak kerap.

\section{Analisa Maklum Balas faktor yang mempengaruhi perubahan aktiviti sosial pengguna di Malaysia}

Bagi mengkaji faktor yang mempengaruhi perubahan aktiviti sosial kosumer di Malaysia selepas berlakunya wabak pandemik COVID-19, 4 item soalan telah dibina secara dalam talian. Jadual 3 menunjukkan peratusan dapatan kajian bagi setiap item untuk mengkaji aktiviti sosial konsumer di Malaysia selepas wabak pandemik COVID-19. Item soalan ini telah dibina dengan menggunakan skala likert 1 hingga 5 iaitu skala 1 ialah sangat tidak setuju (STS), skala 2 tidak setuju (TS), skala 3 tidak pasti (TP), skala 4 setuju (S) dan skala 5 adalah sangat setuju (SS).

Hasil daripada item soalan 1 menunjukkan faktor yang mempengaruhi perubahan aktiviti sosial konsumer di Malaysia adalah kerana majoriti konsumer sangat setuju iaitu seramai 14 responden (46.7\%) dan 13 responden (43.3\%) setuju bahawa adalah kerana mereka menjadi paranoid terhadap virus COVID-19 yang masih lagi bebas di sekeliling kita dan masih lagi belum menemui vaksin. Namun ada juga yang menyatakan tidak pasti iaitu seramai 3 responden (10\%). Ini adalah kerana mungkin mereka lebih berasa perlu berjaga-jaga dan bukan paranoid terhadap virus tersebut.

Bagi item soalan kedua pula majoriti sangat setuju bahawa mereka mengamalkan sikap berhati-hati iaitu seramai 18 responden $(60 \%)$ dan setuju seramai 9 responden (30\%). Ini adalah kerana mereka tidak mahu diri mereka dijangkiti virus COVID-19 ini Ketika mereka giat melakukan aktiviti sosial. Namun ada seorang responden yang menjawab sangat tidak setuju (3.3\%) dan 2 responden $(6.7 \%)$ yang menjawab tidak pasti.

Jadual 3: Faktor yang Mempengaruhi Perubahan Aktiviti Sosial

\begin{tabular}{|c|c|c|c|c|c|}
\hline \multirow[t]{2}{*}{ Kenyataan } & 1 & 2 & 3 & 4 & 5 \\
\hline & STS & TS & $\mathbf{T P}$ & $\mathbf{S}$ & SS \\
\hline \multirow{2}{*}{$\begin{array}{l}\text { Penduduk menjadi paranoid } \\
\text { terhadap virus COVID-19 }\end{array}$} & 0 & 0 & 3 & 13 & 14 \\
\hline & $(0 \%)$ & $(0 \%)$ & $(10 \%)$ & $(43.3 \%)$ & $(46.7 \%)$ \\
\hline Penduduk mengamalkan & 1 & 0 & 2 & 9 & 18 \\
\hline
\end{tabular}




\begin{tabular}{llllll}
\hline sikap berhati-hati & $(3.3 \%)$ & $(0 \%)$ & $(6.7 \%)$ & $(30 \%)$ & $(60 \%)$ \\
Penduduk patuh terhadap & 0 & 3 & 5 & 10 & 12 \\
SOP yang telah ditetapkan & $(0 \%)$ & $(10 \%)$ & $(16.7 \%)$ & $(33.3 \%)$ & $(40 \%)$ \\
$\begin{array}{l}\text { Penduduk ingin } \\
\text { mengurangkan risiko }\end{array}$ & 0 & 0 & 3 & 10 & 17 \\
$\begin{array}{l}\text { dijangkiti } \\
\text { virus COVID-19 }\end{array}$ & $(0 \%)$ & $(0 \%)$ & $(10 \%)$ & $(33.3 \%)$ & $(56.7 \%)$ \\
\hline
\end{tabular}

Untuk item soalan ketiga pula majoriti menjawab sangat setuju iaitu serama 12 responden (40\%) dan setuju seramai 10 responden (33.3\%). Ini adalah kerana kebanyakan pengguna mematuhi SOP yang telah dikeluarkan oleh kerajaan ketika hendak melakukan aktiviti sosial ataupun sekiranya tiada perkara penting yang hendak dilakukan pengguna dinasihatkan untuk duduk di rumah sahaja atau menggunakan perkhidmatan talian. Namun ada responden yang menjawab tidak pasti iaitu seramai 5 responden (16.7\%). Ini adalah kerana responden ini tidak pasti sama ada perubahan aktiviti sosial konsumer berubah disebabkan kerana pengguna patuh pada SOP atau pun tidak. Seramai 3 responden (10\%) yang menjawab tidak setuju. Ini adalah kerana responden ini tidak bersetuju bahawa faktor perubahan aktiviti sosial konsumer adalah disebabkan pengguna patuh pada SOP yang telah ditetapkan.

Untuk item soalan yang terakhir pula majoriti sangat setuju bahawa pengguna ingin mengurangkan risiko dijangkiti virus COVID-19 iaitu seramai 17 responden (56.7\%) dan setuju seramai 10 responden (33.3\%). Disebabkan pengguna ingin mengurangkan risiko dijangkiti maka aktiviti sosial pengguna berubah iaitu mereka tidak kerap melakukan aktiviti sosial seperti biasa sebelum berlakunya pandemik. Namun ada responden yang menjawab tidak pasti iaitu seramai 3 responden (10\%).

\section{Perbincangan}

Objektif kajian ini adalah untuk mengkaji aktiviti sosial konsemur sebelum berlakunya pandemik COVID-19, aktiviti sosial konsumer selepas pandemik COVID-19 dan juga faktor yang mempengaruhi perubahan aktiviti konsumer di Malaysia. Hasil daripada soal selidik secara dalam talian yang telah dijawab oleh 30 responden telah menunjukkan berlaku perubahan terhadap aktiviti sosial konsumer sebelum dan selepas pandemik COVID-19. Sebelum berlakunya pandemik COVID19 ini aktiviti sosial konsumer agak bebas dan lebih giat melakukan aktivti sosial tanpa perlu risau tentang virus yang sedang merebak. Antara aktiviti sosial konsumer sebelum berlakunya pandemik adalah mereka kerap pergi membeli-belah di pusat membeli-belah tanpa perlu risau terhadap virus yang bakal menjangkiti mereka. Kedai-kedai makan sering dipenuhi oleh konsumer yang gemar untuk berkumpul beramai-ramai bersama rakan-rakan dan ahli keluarga. Selain itu, aktiviti sosial seperti berkunjung ke pusat kecergasan seperti gym pada setiap hari atau setiap minggu juga merupakan antara salah satu aktiviti sosial yang sering dilakukan oleh konsumer apabila mereka mempunyai masa lapang untuk menghilangkan tekanan daripada tempat kerja.

Ada di antara konsumer yang memiliki kad ahli bagi sesebuah pusat kecergasan yang mereka perlu bayar yurannya pada setiap bulan bagi mendapatkan kelebihan yang banyak di pusat kecergasan tersebut. Tambahan lagi, aktiviti sosial yang sering dilakukan oleh konsumer adalah seperti pergi bercuti bersama ahli keluarga dan rakan sama ada dalam negara atau luar negara. Aktiviti ini merupakan satu aktiviti yang wajib dilakukan oleh setiap orang. Ramai yang mengambil peluang untuk melepaskan tekanan dengan melawat negara lain selain Malaysia. Mereka sanggup berbelanja dengan banyak untuk menenangkan fikiran mereka dengan pergi bercuti. Tiada halangan atau sekatan dari kerajaan kepada semua konsumer untuk pergi bercuti. Pengguna bebas untuk memilih destinasi yang mereka impikan untuk pergi bercuti. Akhir sekali pada waktu sebelum berlakunya pandemik ini konsumer kebiasaannya kurang menggunakan perkhidmatan atas talian. Mereka lebih suka untuk berkunjung sendiri ke kedai atau pusat membeli-belah untuk membeli sesuatu yang mereka perlukan. Melihat barangan di depan mata sebelum membeli adalah satu kepuasan bagi seorang konsumer kerana mereka boleh melihat jenis kualiti bagi barangan tersebut. 
Namun selepas berlakunya pandemik COVID-19 ini perubahan terhadap aktiviti sosial konsumer mula menampakkan perubahan yang agak ketara. Di mana peratusan konsumer mengunjungi pusat membeli-belah agak menurun tidak seperti sebelum berlakunya pandemik. Selain itu, pengguna juga mula memakai pelitup muka dan "scan" MySejahtera dan menggunakan "hand sanitizer". Ini adalah untuk mudah mengenal pasti jika ada di antara individu yang mengunjungi pusat membeli-belah tersebut positif COVID-19. Tambahan lagi, konsumer sudah mula tidak berkunjung ke kawasan yang sesak dengan orang ramai seperti pergi ke taman-taman rekreasi yang kebiasaannya dipenuhi oleh orang ramai yang ingin menghabiskan masa lapang mereka dengan ahli keluarga. Kini mereka menghabiskan masa dengan ahli keluarga dengan melakukan aktiviti di rumah sahaja. Konsumer juga sudah mula kurang untuk mengunjungi pusat kecergasan seperti gym, futsal atau badminton. Aktiviti sukan yang berkumpulan dilihat berlaku satu perubahan yang ketara selepas berlakunya pandemik ini dimana aktiviti bersukan secara berkumpulan atau di tempat ramai orang adalah tidak digalakkan oleh kerajaan sendiri. Selain itu, pihak pusat kecergasan juga telah mengikut SOP yang ditetapkan oleh kerajaan dimana mereka perlu mengehadkan jumlah pengguna pada satu-satu masa dan juga perlu mengurangkan jumlah pengunjung. Ini telah menyebabkan pengguna kurang datang ke pusat kecergasan dan hanya melakukan aktiviti bersukan secara sendiri di kawasan taman perumahan atau taman rekreasi dimana mereka tidak ada melakukan sebarang kontak dengan orang lain.

Seterusnya, pengguna tidak lagi dapat melakukan aktiviti bercuti bersama ahli keluarga atau rakan sama ada di dalam negara atau luar negara. Aktiviti ini merupakan satu aktiviti yang menyumbang jumlah besar dalam kes positif dimana kebanyakan orang yang balik dari pergi bercuti telah disahkan positif COVID-19. Jadi aktiviti ini bukanlah lagi aktiviti yang dilakukan oleh pengguna. Impaknya industri penerbangan dan perhotelan menanggung kerugian yang amat besar sehingga terpaksa memberhentikan pekerja mereka akibat daripada mereka tidak mempunyai pelanggan atau pengguna untuk menggunakan perkhidmatan mereka. Namun, bagi industri perkhidmatan atas talian telah melonjak naik seperti aplikasi Lazada, Shopee, GrabFood, FoodPanda dan banyak lagi telah mendapat sambutan yang cukup tinggi selepas daripada pandemik ini. Ini adalah kerana pengguna telah mengubah aktiviti daripada pergi ke pusat membeli-belah atau ke kedai makan dengan memesan secara dalam talian sahaja dan barang atau makanan yang mereka inginkan akan sampai ke depan pintu rumah mereka.

Terdapat pelbagai faktor yang telah menyebabkan berlakunya perubahan terhadap aktiviti sosial konsumer selepas berlakunya pandemik COVID-19 ini. Antaranya adalah pengguna mula menjadi paranoid terhadap virus COVID-19 ini. Pengguna majoriti bersetuju bahawa punca aktivti sosial mereka berubah adalah kerana mereka berasa tidak selamat untuk melakukan aktiviti sosial yang telah menjadi kebiasaan mereka dengan adanya virus ini di sekeliling mereka. Mereka mula mengubah aktiviti harian mereka dengan lebih selamat dengan cuba sedaya upaya untuk tidak melakukan kontak dengan orang ramai. Selain itu, pengguna juga mengamalkan sikap berhati-hati dalam melakukan aktiviti mereka dengan tidak keluar ke rumah tanpa ada sebarang hal yang penting. Sikap berhati-hati ini telah mengubah sedikit sebanyak aktiviti sosial mereka dimana mereka mula untuk cuba melakukan pembelian secara dalam talian dan hanya jika perlu sahaja mereka akan ke kedai atau pusat membeli-belah. Tambahan pula, faktor yang mempengaruhi perubahan aktiviti sosial pengguna adalah rakyat telah mula patuh dan mengikut SOP yang telah ditetapkan oleh kerajaan dimana setiap premis tidak boleh mempunyai pelanggan yang ramai pada satu-satu masa.

Ini telah menyebabkan pengguna lebih gemar untuk membeli secara atas talian kerana mereka tidak perlu beratur untuk masuk ke satu-satu premis. Selain itu, setiap kali hendak memasuki mana-mana pusat membeli-belah atau premis pengguna perlu "scan" MySejahtera keran itu merupakan SOP ketat yang telah ditetapkan oleh kerajaan. Hal ini telah menyebabkan pengguna merasa ianya adalah perkara yang melambatkan aktiviti mereka untuk membeli belah. Sebagai contoh pengguna mengunjungi Johor Premium Outlet (JPO) dan sebelum memasuki JPO pengguna perlu mengimbas MySejahtera dan apabila mereka hendak memasuki setiap premis yang ada di dalam JPO mereka perlu mengimbas lagi MySejahtera dan ini membuatkan pengguna mula menggunakan perkhidmatan atas talian yang jauh lebih cepat dan mudah. Faktor yang terakhir adalah pengguna ingin mengurangkan risiko daripada dijangkiti virus COVID-19. Ini telah menyebabkan pengguna lebih banyak menghabiskan 
masa di rumah dan tidak keluar rumah untuk berbelanja namun berbelanja secara atas talian. Pengguna juga sudah mula tidak berkunjung ke pusat membeli belah, pusat kecergasan, taman rekreasi atau pergi bercuti untuk mengelak daripada risiko merak dijangkiti virus ini.

Secara kesimpulan, empat faktor yang telah dinyatakan iaitu pengguna menjadi paranoid terhadap virus COVID-19, pengguna mengamalkan sikap berhati-hati, pengguna patuh terhadap SOP yang telah ditetapkan dan pengguna ingin mengurangkan risiko dijangkiti virus COVID-19 ini telah menjadi punca atau penyebab berlakunya perubahan terhadap aktiviti sosial konsumer di Malaysia selepas berlakunya pandemik COVID-19.

\section{Kesimpulan dan Cadangan}

Salah satu isu yang berlaku disebabkan pandemik COVID-19 ialah masyarakat terbatas dalam melakukan aktiviti harian seperti biasa. Masyarakat dihadkan untuk melakukan aktiviti sosial atau riadah terutamanya di tempat awam. Berikutan dari wabak ini, secara tidak langsung rakyat Malaysia telah menjalani kehidupan norma baharu yang sangat berlainan dengan kehidupan biasa sebelum pandemik COVID-19. Isu pandemik COVID-19 ini telah memberi kesan terhadap pengguna dari aspek aktiviti sosial dalam kehidupan masyarakat. Dari hasil kajian ini, kesan norma baharu terhadap pengguna dari aspek aktiviti sosial menunjukkan pengguna menjadi paranoid terhadap virus COVID19, pengguna mengamalkan sikap berhati-hati, pengguna patuh terhadap Standard Operating Procedure (SOP) yang telah ditetapkan dan pengguna ingin mengurangkan risiko dijangkiti virus COVID-19 ini telah menjadi punca atau penyebab berlakunya perubahan terhadap aktiviti sosial konsumer di Malaysia selepas berlakunya pandemik COVID-19. Kerajaan terpaksa menjalankan Perintah Kawalan Pergerakan (PKP) supaya wabak ini tidak merebak dengan lebih teruk. Masyarakat juga dinasihatkan supaya mengawal pergerakan seperti terus kekal berada di rumah, bekerja dari rumah (Work From Home), dan pergerakan di luar rumah perlu dihadkan. Masyarakat seperti pengguna perlu mengikut SOP ketika berada di kawasan awam atau di luar rumah. Antaranya ialah masyarakat perlu memakai pelitup hidung dan mulut, kerap cuci tangan dan menjaga penjarakan sosial sebagai langkah-langkah pencegahan pandemik ini.

\section{Rujukan}

Adnan, H., \& Adnan, W. Z. W. (2020). Impak Pandemik COVID-19: Kajian keberkesanan proses pendaftaran pelajar dan hari suai kenal pelajar baharu sebelum dan semasa Perintah Kawalan Pergerakan Pemulihan (PKPP). ANP Journal of Social Science and Humanities, 1(1), 1-6.

Aziz, A. R. A., Sukor, N. M., \& Ab Razak, N. H. (2020). Wabak Covid-19: Pengurusan Aspek Kesihatan Mental Semasa Norma Baharu. International Journal of Social Science Research, 2(4), 156-174.

Basir, N., Ab Rahim, I. S., \& Halim, M. Z A. (2020). Analisis tingkah laku sosiologi masyarakat berasaskan teori interaksionisme melalui perangkaan data kes COVID-19 di Malaysia. PENDETA: Journal of Malay Language, Education and Literature, 11, 11-30.

Jaafar, N. F., Zain, A., \& Eshak, Z. (2020). Peranan ibu bapa dalam membantu perkembangan sosial kanak-kanak melalui aktiviti bermain semasa perintah kawalan pergerakan. Jurnal Pendidikan Awal Kanak-Kanak Kebangsaan, 9, 52-60.

Rashid, S. M. R. A., \& Hassan, F. (2020). Amalan dan penglibatan peniaga kecil melalui perniagaan digital semasa Pandemik COVID-19 di Malaysia. GEOGRAFI, 8(2), 1-20. 